\title{
The Rule of Law and the Law of the Sea
}

\author{
An Editorial Note to the Special Issue
}

\author{
Keyuan Zou \\ Distinguished Professor, School of Law, Dalian Maritime University, Dalian, \\ China \\ zoukeyuan@dlmu.edu.cn
}

The term 'rule of law' is a common jargon which frequently appears in government documents, national laws, literature and media. As defined by Black's Law Dictionary, the rule of law is 'a legal principle, of general application, sanctioned by the recognition of authorities, and usually expressed in the form of a maxim or logical proposition', and 'the rule of law, sometimes called "the supremacy of law", provides that decisions should be made by the application of known principles or laws without the intervention of discretion in their application.' ${ }^{1}$ According to A.V. Dicey, the concept of the rule of law should contain two principles: the supremacy or predominance of regular law (as opposed to the influence of arbitrary power) and equality before the law (or the equal subjection of all classes to the ordinary law of the land administered by the ordinary law courts). ${ }^{2}$ It can be seen that there are at least two essential elements in the definition of the rule of law: supremacy of law, and equality before the law.

While the concept of rule of law is mainly embodied in the domestic legal systems, ${ }^{3}$ it is recently extended to the international arena for global governance. The United Nations has started its discussions of the rule of law at both national and international levels since 2006. As expressed by the United Nations, 'the rule of law is a principle of governance in which all persons, institutions and entities, public and private, including the State itself, are

1 Black's Law Dictionary, 6th Edition (West Group, St Paul, Minnesota, 1990), at 1332.

2 See A.V. Dicey, 'The Rule of Law', in F.L. Morton (Ed.), Law, Politics and the Judicial Process in Canada, 2nd Edition (University of Calgary Press, Calgary, 1992), at 17.

3 For example, the amended Chinese Constitution in 1999, in Article 5, adds, 'the People's Republic of China implements law to govern the State and construct the socialist country in accordance with the rule of law'. The English version is available in BEIJING REVIEW, 3-9 May 1999, at 14-15. 
accountable to laws that are publicly promulgated, equally enforced and independently adjudicated, and which are consistent with international human rights norms and standards. It requires measures to ensure adherence to the principles of supremacy of the law, equality before the law, accountability to the law, fairness in the application of the law, separation of powers, participation in decision-making, legal certainty, avoidance of arbitrariness, and procedural and legal transparency.'4 The rule of law is fundamental to international peace and security and political stability, and rule of law-based society should be considered as an outcome of the 2030 Agenda and Sustainable Development Goals (SDGs). ${ }^{5}$

When it comes to the rule of law in the context of ocean governance, it is universally agreed that a set of norms of rules centered on the UN Convention on the Law of the Sea (LOSC) is most relevant and important. The LOSC is described as a 'constitution for the oceans' 6 and governs the oceans and human ocean activities in almost all aspects. While the LosC is a most important international treaty in the law of the sea, other important treaties such as the Convention on Biological Diversity and the UN Framework Convention on Climate Change are also applicable to ocean governance. In addition, customary international law plays a very significant role in this respect as well.

Against the above background, the Dalian Maritime University School of Law timely organized the 8th Ocean Law and Governance International Symposium with the theme 'Rule of Law and the Law of the Sea' held in Dalian, China, in October 2019. This special issue is a collection of the selected papers originally presented at the Symposium and later revised and updated. They touch upon various ocean issues in the context of the rule of law, ranging from codification and development of the international law of the sea including the contributions of international courts, the rule of law for the realization of the SDGs at sea, particularly SDG14, to the improvement and possible amendment of the LOSC.

4 See United Nations, 'What Is The Rule Of Law', available at https://www.un.org/ ruleoflaw/what-is-the-rule-of-law/. For further information, see B. Fassbender, What's in a Name? The International Rule of Law and the United Nations Charter, 17 (3) Chinese Journal of International Law (2018), at $761-797$.

5 United Nations, Ibid.

6 See Tommy T.b. Koh, 'A Constitution for the Oceans', available at https://www.un.org/Depts/ los/convention_agreements/texts/koh_english.pdf. For further discussion, see B.H. Oxman, The Rule of Law and the United Nations Convention on the Law of the Sea, 7 European Journal of International Law (1996), at 353-371. 
This special issue reflects the most updated intellectual discussions and debates on the rule of law for the oceans and will benefit such continuing discussions and debates on the one hand, and possibly contribute to the ongoing discussions on the rule of law within the UN system on the other. I express my sincere gratitude to all the contributors for their respective papers contained in this special issue as well as to the Dalian Maritime University School of Law for hosting the Symposium. I also render my sincere thanks to the Korean Journal of International and Comparative Law for publishing this special issue. 